\title{
Pengujian validitas dan reliabilitas konstruk hope
}

\author{
Husnawati \\ Magister Psikologi, Program Pascasarjana, Universitas Ahmad Dahlan \\ husnawatipsi@gmail.com \\ Fatwa Tentama \\ Magister Psikologi, Program Pascasarjana, Universitas Ahmad Dahlan \\ fatwa.tentama@psy.uad.ac.id \\ Nina Zulida Situmorang \\ Magister Psikologi, Program Pascasarjana, Universitas Ahmad Dahlan \\ nina.situmorang@psy.uad.ac.id
}

\begin{abstract}
ABSTRAK
Hope adalah energi yang memotivasi seseorang dalam melakukan pekerjaannya. Hope sebagai energi yang difokuskan pada tujuan seseorang dan merupakan jalan yang menuntun seseorang pada tujuannya. Hope sangat penting dimiliki dan dikembangkan dalam diri manusia, salah satunya untuk meningkatkan kepuasan hidup seseorang. Hope berperan penting atau mendukung dalam membantu individu untuk mencapai tujuan positif dan membangkitkan perasaan baik atau motivasi untuk membuat mimpi menjadi kenyataan dalam kehidupan manusia. Hope sangat dibutuhkan oleh individu, karena dengan adanya hope maka akan memberikan dampak positif dalam kehidupannya. Menurut Snyder terdapat tiga komponen yang merefleksikan konstruk hope antara lain goal, pathway thinking, dan agency thinking. Penelitian ini bertujuan untuk menguji validitas dan reliabilitas konstruk skala hope, serta mengetahui kontribusi komponen-komponen dan aitem-aitem (indikator) hope dalam merefleksikan/mengukur konstruk hope baik yang paling dominan ataupun sebaliknya. Subjek dalam penelitian ini adalah guru sekolah negeri di Yogyakarta yang berjumlah 66 orang. Pengumpulan data menggunakan skala psikologis, yaitu skala hope. Analisis data dilakukan dengan menggunakan program Structure Equation Modeling (SEM) dengan metode analisis data Partial Least Squares (PLS), dengan menggunakan softwere Smart PLS 3.0. Validitas dan reliabilitas alat ukur pada konstruk hope dalam Partial Least Squares (PLS) diukur menggunakan outer model. Hasil analisis menunjukkan bahwa ketiga komponen mampu merefleksikan konstruk hope secara positif, valid, dan reliabel yang didukung dengan indikator-indikator perilaku masing-masing komponen, sehingga skala hope ini dapat dimanfaatkan sebagai alat ukur dalam penelitian. Kontribusi komponen yang paling dominan dalam merefleksikan konstruk hope adalah komponen agency thinking (TA), sedangkan kontribusi komponen yang paling kecil adalah komponen goal (GA).
\end{abstract}

Kata Kunci: Hope, Reliabilitas, Validitas

\begin{abstract}
Hope is the energy that motivates someone in doing their work. Hope as energy is focused on one's goals and is the path that guides someone to their goals. Hope is very important to have and develop in humans, one of which is to increase one's life satisfaction. Hope plays an important or supportive role in helping individuals to achieve positive goals and arouse good feelings or motivation to make dreams come true in human life. Hope is really needed by individuals, because with hope it will have a positive impact on their lives. According to Snyder there are three components that reflect the construct of hope, including goals,
\end{abstract}


Jurnal Psikologi Terapan dan Pendidikan

ISSN: $2715-2456$

Vol. 1, No. 2, November 2019, pp. 128-135

pathway thinking, and agency thinking. This study aims to test the validity and reliability of the hope scale construct, and to find out the contribution of the components and hope items in the reflection / measure of the construct expectations either the most dominant or vice versa. The subjects in this study were 66 public school teachers in Yogyakarta. The data collecting uded psychological instrument, namely the hope scale. Data analysis was performed using the Structure Equation Modeling (SEM) program with the Partial Least Squares (PLS) data analysis method, namely Smart PLS 3.0. The validity and reliability of measuring instruments in the hope construct in Partial Least Squares (PLS) are measured using an outer model. The analysis shows that the three components are able to reflect the construct of hope positively, validly, and reliably which is supported by behavioral indicators of each component, so that the hope scale can be used as a measurement tool in research. The contribution of the most dominant component in reflecting the construct of hope is the agency thinking (TA) component, while the contribution of the smallest component is the goal component (GA).

Key Words: Hope, Reliability, Validity

\section{PENDAHULUAN}

Manusia memiliki hal-hal positif yang harus dikembangkan dalam dirinya. Salah satu hal positif yang harus dikembangkan dalam diri manusia ialah hope. Setiap individu memiliki hope yang berbedabeda. Hope individu untuk mencapai sebuah keinginan di masa mendatang dalam kehidupannya tentu saja membutuhkan energi dan motivasi yang kuat untuk mewujudkannya. Snyder, Irving, dan Anderson (1991) mendefinisikan hope sebagai "keadaan motivasi positif yang didasarkan pada rasa yang diturunkan secara interaktif tentang keberhasilan (a) agency (energi yang diarahkan pada tujuan) dan (b) patways (perencanaan untuk memenuhi tujuan)". Menurut Lindley dan Joseph (2004) hope mencerminkan penilaian individu terkait kapasitas mereka untuk mengkonseptualisasikan tujuan-tujuan dengan jelas, mengembangkan strategi spesifik untuk mencapai tujuan tersebut (pathway thinking), menginisiasi dan mempertahankan motivasi untuk menggunakan strategi tersebut (agency thinking).

Lopez dan Snyder (2004) menjelaskan hope sebagai keyakinan inividu dalam mencapai kemampuan akan keinginan yang kuat, terlepas dari besarnya dorongan yang menandai awal keberadaannya. Hope merupakan pikiran atau keyakinan yang memungkinkan individu untuk mempertahankan tindakan atau perilaku menuju tujuan yang ingin dicapai. Hope adalah energi yang memotivasi seseorang dalam melakukan pekerjaannya. Hope sebagai energi yang difokuskan pada tujuan seseorang dan merupakan jalan yang menuntun seseorang pada tujuannya. Hope merupakan proses dari pemikiran satu tujuan, dengan motivasi untuk mendapatkan tujuan-tujuan tersebut (agency), dan cara-cara untuk meraih tujuan-tujuan tersebut (pathways) (Synder, 2000).

Alasan mengapa hope sangat penting dimiliki dan dikembangkan dalam diri manusia salah satunya untuk meningkatkan kepuasan hidup seseorang seperti beberapa penelitian yang menunjukkan bahwa hope berkorelasi positif dengan kepuasan hidup, kepuasan kerja, kinerja, dan motivasi untuk mengatasi peristiwa 
Jurnal Psikologi Terapan dan Pendidikan

ISSN: $2715-2456$

Vol. 1, No. 2, November 2019, pp. 128-135

yang menimbulkan stres (Çavuş \& Gökçen, 2015). Hope berperan penting atau mendukung dalam membantu individu untuk mencapai tujuan positif atau keinginan untuk membuahkan hasil yang positif dan membangkitkan perasaan baik atau motivasi untuk membuat mimpi menjadi kenyataan dalam kehidupan manusia. Hope dapat ditentukan sebagai komponen yang menyadarkan atau membangkitkan orang untuk menjadi lebih termotivasi dalam hidupannya (Çavuş \& Gökçen, 2015). Umphrey dan Sherblom (2014) mengungkapkan dalam penelitiannya bahwa hope dapat mempengaruhi kepuasan hidup seseorang dimana pemikiran yang penuh dengan hope dapat meningkatkan kepuasan hidup. Lu dan Hsu (2013) menemukan bahwa meningkatkan hope dapat bermanfaat bagi subjectif well-being seseorang. Hal ini mengartikan bahwa semakin semakin tinggi hope yang dimiliki seseorang, maka kebahagian yang dirasakan juga akan meningkat.

Melihat pentingnya hope tersebut maka penelitian tentang validitas dan reliabilitas konstruk hope penting dilakukan, karena apabila hope juga dapat dimiliki dan ditingkatkan oleh guru, maka dimungkinkan guru tersebut akan merasakan kebahagiaan dan hal-hal positif lainnya dalam kehidupannya. Terdapat tiga komponen yang merefleksikan hope menurut Snyder (2000) yaitu goal, pathway thinking, dan agency thinking. Goal berarti perilaku manusia yang berorientasi dan memiliki arah tujuan. Goal merupakan sasaran dari tahapan tindakan mental yang menghasilkan komponen kognitif. Goal merupakan setiap objek, pengalaman, atau hasil yang dibayangkan dan diinginkan individu dalam benaknya. Goal dapat berupa kongkrit atau abstrak, dan bersifat jangka pendek dan jangka panjang, tetapi harus sesuatu yang penting untuk dicapai. Goal juga harus mungkin untuk dicapai, bukan sesuatu yang mustahil dicapai.

Pathway thinking adalah kemampuan seseorang untuk mengembangkan suatu jalur untuk mencapai tujuan yang diinginkan. Individu yang ingin mencapai tujuan harus memandang dirinya sebagai individu yang memiliki kemampuan untuk mengembangkan suatu jalur untuk mencapai tujuan. Agency thinking yaitu kapasitas untuk menggunakan suatu jalur untuk mencapai tujuan yang diinginkan. Agency mencerminkan persepsi individu bahwa ia mampu mencapai tujuannya melalui jalur-jalur yang dipikirkannya, agency juga dapat mencerminkan penilaian individu mengenai kemampuannya bertahan ketika menghadapi hambatan dalam mencapai tujuan. Individu yang memiliki agency thinking tinggi dengan kata lain bahwa individu tersebut memiliki keinginan yang kuat untuk melakukan usaha dalam mencapai tujuan yang diinginkannya (Snyder, 2000).

Validitas dan reliabilitas konstruk dari indikator-indikator (aitem-aitem) pembentuk konstruk laten (konstruk hope) dilakukan dengan Confirmatory Factor Analysis (CFA). Pada penelitian ini model struktural yang digunakan yaitu outer model atau disebut dengan model pengukuran untuk menilai validitas dan reliabilitas (Jogiyanto, 2011), serta menggunakan model pengukuran reflektif pada jenjang second 
Jurnal Psikologi Terapan dan Pendidikan

ISSN: $2715-2456$

Vol. 1, No. 2, November 2019, pp. 128-135

order construct (SOC) yang terdapat pada Partial Least Squares (PLS). SOC ialah hubungan teoritis antara variabel laten dengan dimensi konstruk di bawahnya (Jogiyanto, 2011). Tujuan penelitian ini yaitu pertama untuk menguji validitas konstruk dan reliabilitas konstruk skala hope, dan kedua untuk mengetahui kontribusi komponen-komponen dan indikator-indikator hope dalam merefleksikan atau mengukur konstruk hope baik yang paling dominan atau sebaliknya.

\section{METODE PENELITIAN}

Subjek dalam penelitian ini adalah guru sekolah negeri di Yogyakarta dengan jumlah 66 orang. Metode penelitian yang digunakan yaitu metode kuantitatif. Instrumen yang digunakan untuk mengukur hope dalam penelitian ini adalah skala hope yang dikonstruksikan sendiri oleh penulis berdasarkan komponen-komponen hope dari Snyder (2000) yaitu goal, pathway thinking, dan agency thinking. Skala pengukuran yang digunakan adalah skala semantik differensial. Skala model semantik differensial disusun dalam satu garis kontinum dengan pasangan kata dalam satu pernyataan. Kata yang favourable terletak di bagian kanan dan kata yang unfavourable terletak di bagian kiri dengan skor yang bergerak dari angka 1 sampai 5, sebagaimana pada tabel berikut:

Tabel 1.

Format Respons Konstruk Hope Model Semantik Differensial

\begin{tabular}{lllllll}
\hline Unfavorabel & 1 & 2 & 3 & 4 & 5 & Favorabel \\
\hline
\end{tabular}

Validitas dan reliabilitas alat ukur pada konstruk hope menggunakan outer model dalam Partial Least Squares (PLS) dari aplikasi SmartPLS 3.0. Outer model merupakan model pengukuran untuk menilai validitas dan reliabilitas model (Jogiyanto, 2011). Validitas dalam Partial Least Squares (PLS) berfungsi untuk menganalisis konstruk hope, yaitu melalui validitas konvergen dan validitas diskriminan.

Validitas konvergen digunakan untuk mengukur besarnya korelasi antara variabel laten dengan konstruknya, dengan standarized loading factor. Menurut Hair (2006), rule of tumb yang digunakan untuk menguji validitas konvergen adalah nilai loading factor $>0,5$ yang dianggap signifikan secara praktikal dan average variance extracted (AVE) > 0,5 (Jogiyanto, 2011). Validitas diskriminan yaitu besarnya nilai loading antara aspek/komponen dengan aspek/komponen yang lebih besar dibandingkan dengan nilai aspek/komponen lainnya. Nilai tersebut dapat dilihat dengan membandingkan akar average variance extracted (AVE), suatu aspek/komponen harus lebih tinggi dibandingkan dengan korelasi antara aspek/komponen laiinya (Jogiyanto, 2011).

Reliabilitas dalam Partial Least Squares (PLS) berfungsi untuk menganalisis konstruk hope, yaitu dengan cara melihat nilai Cronbach's alpha dan Composite reliability. Fungsi Cronbach's alpha untuk 
Jurnal Psikologi Terapan dan Pendidikan

ISSN: $2715-2456$

Vol. 1, No. 2, November 2019, pp. 128-135

mengukur batas bawah nilai reliabilitas suatu konstruk, sedangkan Composite reliability digunakan untuk menunjukkan internal consistency dan nilai konsistensi dari setiap aitem dalam mengukur variabel laten atau mengukur nilai sesungguhnya reliabilitas suatu konstruk. Nilai Cronbach's alpha dan Composite reliability yang diharapkan adalah >0,7 (Jogiyanto, 2011).

Tabel 2.

\begin{tabular}{|c|c|c|c|c|}
\hline No & Komponen & Indikator & No. Aitem & $\Sigma$ \\
\hline 1 & Goal & $\begin{array}{ll}\text { a. } & \text { Berorientasi pada tujuan } \\
\text { b. Bertujuan berjangka pendek ataupun } \\
\text { panjang baik bersifat abstrak } \\
\text { maupun kongkret }\end{array}$ & $1,2,3,4$ & 4 \\
\hline 2 & $\begin{array}{l}\text { Patway } \\
\text { thinking }\end{array}$ & $\begin{array}{l}\text { a. Mampu merancang strategi } \\
\text { b. Merasa mampu mengembangkan } \\
\text { strategi }\end{array}$ & $5,6,7,8$ & 4 \\
\hline 3 & $\begin{array}{l}\text { Agency } \\
\text { thinking }\end{array}$ & $\begin{array}{l}\text { a. Mempertahankan motivasi } \\
\text { b. Bertahan ketika menghadapi } \\
\text { hambatan }\end{array}$ & $9,10,11,12$ & 4 \\
\hline & & Total & & 12 \\
\hline
\end{tabular}

\section{HASIL DAN PEMBAHASAN}

Berdasarkan hasil analisis yang telah dilakukan bahwa konstruk hope dapat diketahui valid dan reliabel. Validitas konvergen dapat diketahui dengan melihat nilai loading factor dan average variance extracted (AVE), aitem-aitem yang telah valid pada konstruk hope dapat dilihat pada tabel 3 dan gambar 1. Berdasarkan hasil analisis yang telah dilakukan bahwa semua aitem (indikator) dari konstruk hope dapat dikatakan valid, karena semua aitem tersebut memiliki nilai loading factor $>0,5$ dan nilai average variance extracted (AVE) $>0,5$.

Tabel 3.

Nilai Loading Factor dan Avarage Variance Extracted (AVE) Konstruk Hope

\begin{tabular}{cccc}
\hline Konstruk & Nomor Aitem & Loading Factor & AVE \\
\hline \multirow{5}{*}{ Hope } & GO1 & 0,849 & \\
GO2 & 0,730 & \\
GO3 & 0,874 & \\
GO4 & 0,784 & \\
& PT5 & 0,903 & 0,634 \\
PT6 & 0,893 & \\
PT7 & 0,914 & \\
PT8 & 0,864 &
\end{tabular}




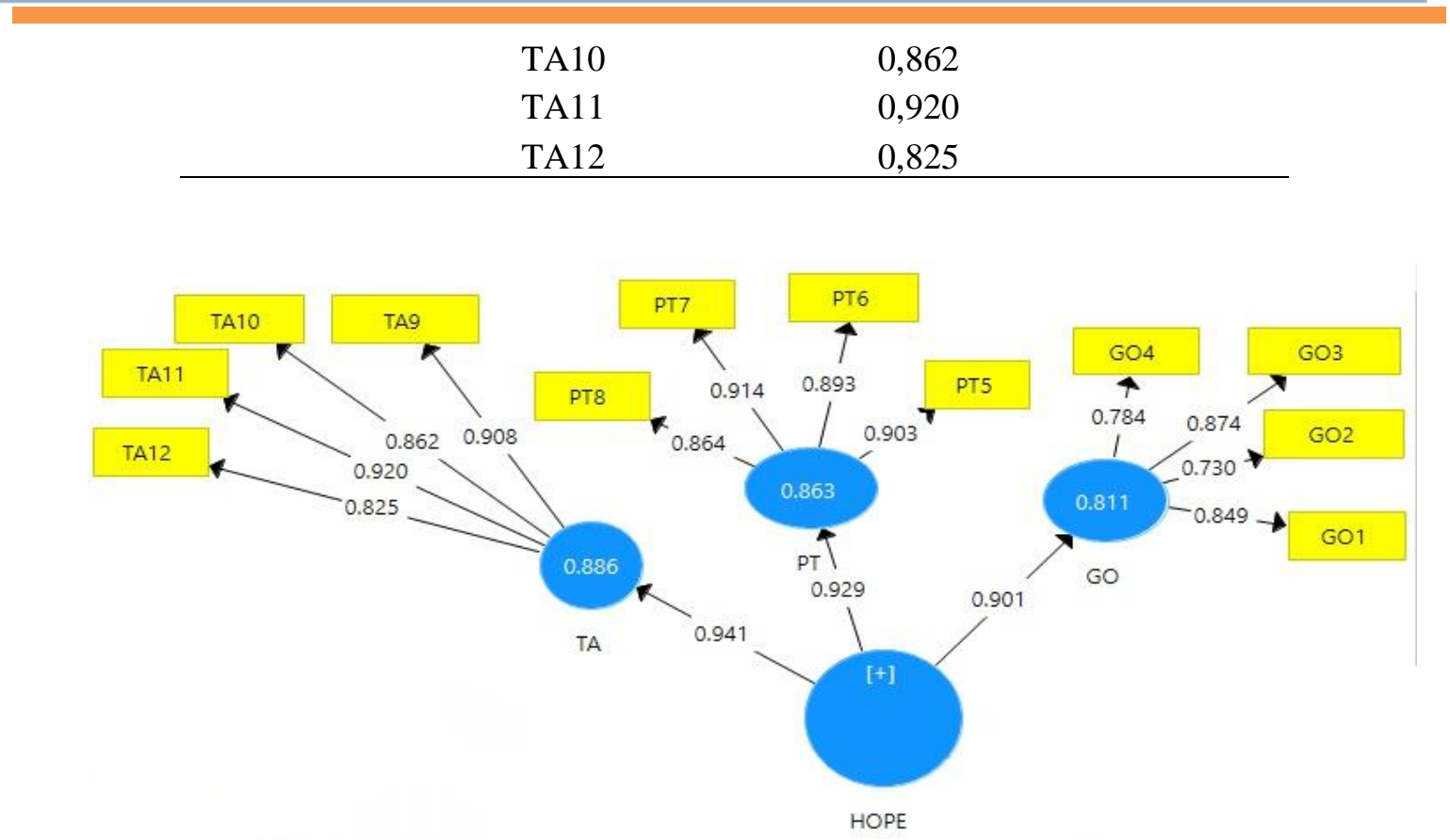

Gambar 1. Output PLS Algorithm Konstruk Hope

Berdasarkan keterangan tabel 3 dan gambar 1, dapat dilihat dan diketahui bahwa ketiga komponen konstruk hope memiliki item-item yang dapat merefleksikan masing-masing komponen pada konstruk hope tersebut. Semua komponen dengan masing-masing item (indikator) valid atau dapat dikatakan bahwa tidak ada aitem yang gugur. Kontribusi komponen yang paling dominan dalam merefleksikan konstruk hope adalah komponen agency thinking (TA) dengan nilai loading factor item (indikator) yang menunjukkan nilai paling besar yaitu terletak pada aitem TA11 dengan nilai sebesar 0,920, serta nilai loading factor item (indikator) yang menunjukkan nilai terkecil pada komponen agency thinking (TA) yaitu terletak pada item TA12 dengan nilai sebesar 0, 825. Kontribusi komponen paling kecil adalah komponen goal (GO) dengan nilai loading factor item (indikator) terbesar yaitu aitem GO3 dengan nilai sebesar 0,874 dan nilai loading factor item (indikator) terkecil yaitu terletak pada aitem GO2 dengan nilai sebesar 0,730.

Tabel 4.

Validitas Diskriminan Komponen-Komponen pada Konstruk Hope

\begin{tabular}{cccc}
\hline Komponen & GO & PT & TA \\
\hline GO & 0,811 & 0,742 & 0,786 \\
PT & 0,742 & 0,893 & 0,814 \\
TA & 0,786 & 0,814 & 0,880 \\
\hline
\end{tabular}

Validitas diskriminan pada komponen-komponen konstruk hope dapat dilihat pada tabel 4. Berdasarkan hasil analisis yang telah dilakukan, dapat diketahui bahwa validitas diskriminan antar 
Jurnal Psikologi Terapan dan Pendidikan

ISSN: $2715-2456$

Vol. 1, No. 2, November 2019, pp. 128-135

komponen sudah terpenuhi yang ditunjukkan dengan nilai akar AVE suatu komponen lebih tinggi dibandingkan dengan korelasi komponen lainnya.

Reliabilitas konstruk hope dapat dilihat dari nilai Cronbach's alpha dan Composite reliability yang diketahui telah reliabel. Nilai Cronbach's alphhopea dan Composite reliability tersebut dapat dilihat pada tabel 5. Berdasarkan tabel 5 berikut ini, bahwa diperoleh nilai Cronbach's alpha sebesar 0,947 dan Composite reliability 0,954, sehingga dapat diketahui bahwa konstruk hope telah memenuhi syarat reliabilitas karena nilai Cronbach's alpha dan Composite reliability > 0,7.

Tabel 5.

Nilai cronbach's Alpha dan Composite Reliability Konstruk Hope

\begin{tabular}{cccc}
\hline Konstruk & Cronbach's Alpha & Composite Reliability & Keterangan \\
\hline Hope & 0,947 & 0,954 & Reliabel \\
\hline
\end{tabular}

Kontribusi tiap komponen dalam merefleksikan konstruk hope dapat dilihat pada tabel 6, yaitu dengan melihat nilai T-Statistic pada setiap komponen. Diketahui bahwa ketiga komponen konstruk hope memiliki aitem yang dapat merefleksikan tiap komponen pada konstruk hope. Konstribusi komponen yang paling dominan dalam merefleksikan konstruk hope adalah komponen agency thinking (TA) dengan nilai T-Statistic sebesar 91,903, sedangkan kontribusi paling kecil adalah komponen goal (GO) dengan nilai nilai T-Statistic sebesar 32,207.

Tabel 6.

Nilai T-Statistic Konstruk Hope

\begin{tabular}{ccc}
\hline Kmponen & T-Statistic & P-Values \\
\hline GO & 32,207 & 0.000 \\
PT & 45,957 & 0.000 \\
TA & 91,903 & 0.000 \\
\hline
\end{tabular}

Berdasarkan penjelasan di atas, maka dapat diketahui bahwa komponen-komponen dan item-item (indikator) pada konstruk hope yaitu valid dan reliabel, sehingga dapat digunakan sebagai alat ukur penelitian yang dapat merefleksikan konstruk hope. Sebaran aitem konstruk hope yang valid dan reliabel dapat dilihat pada tabel 7 berikut ini.

Tabel 7.

Sebaran Item Konstruk Hope yang Valid dan Reliabel

\begin{tabular}{|c|c|c|c|}
\hline No & Aspek & Nomor Aitem & Total \\
\hline 1 & Goal & $1,2,3,4$ & 4 \\
\hline 2 & Pathway thinking & $5,6,7,8$ & 4 \\
\hline 3 & Agency thinking & $9,10,11,12$ & 4 \\
\hline & Total & 12 & 12 \\
\hline
\end{tabular}


Jurnal Psikologi Terapan dan Pendidikan

ISSN: $2715-2456$

Vol. 1, No. 2, November 2019, pp. 128-135

Berdasarkan pemaparan di atas bahwa konstruk hope dapat digunakan untuk penelitian karena semua item (indikator) dari komponen konstruk hope valid dan reliabel serta dapat merefleksikan konstruk hope tersebut dengan baik, sehingga tidak perlu dilakukan penomoran baru karena semua aitem tidak ada yang gugur.

\section{KESIMPULAN}

Berdasarkan hasil analisis yang telah dilakukan pada konstruk hope dapat diketahui bahwa komponen-komponen dan item-item pada konstruk hope valid dan reliabel, sehingga skala hope dapat dimanfaatkan secara maksimal sebagai alat ukur untuk mengukur hope pada guru. Hope mampu direfleksikan dalam tiga komponen pembentuk hope yaitu goal, patway thinking, dan agency thinking. Komponen yang berkontribusi paling dominan atau besar yang merefleksikan hope adalah komponen agency thinking (TA), sedangkan komponen yang berkontribusi paling kecil adalah goal (GO) dengan nilai yang ditunjukkan oleh masing-masing komponen. Seluruh komponen dalam alat ukur ini dapat memenuhi kriteria-kriteria sebagai aitem yang baik.

\section{DAFTAR PUSTAKA}

Cavus, M. \& Gokcen, A. (2015). Psychological capital: Definition, components and effects. British Journal of Education, Society \& Behavioural Science, 5(3), 244-255. doi: 10.9734/BJESBS/2015/12574.

Jogiyanto. (2011). Konsep dan aplikasi structural equation modeling (SEM) berbasis varian dalam penelitian bisnis. Yogyakarta: Unit Penerbit dan Percetakan STIM YKPN Yogyakarta.

Lindley, P. A., \& Joseph, S. (2004). Positive psychology in practice. United States of America: Jhon Wiley \& Sons, Inc.

Lopez, S. J., \& Snyder, C. R. (2003). Positive Psychological Assessment: A Handbook of Models and Measures (American Psychological Association, Washington, DC).

Lu, F. J. H., \& Hsu, Y. (2013). Injured athletes' rehabilitation beliefs and subjective well-being: The contribution of hope and social support. Journal of Athletic Training, 48(1), 92-98. doi:10.4085/1062-6050-48.1.03.

Snyder, C. R., Irving, L. M., \& Anderson, J. R. (1991). Hope and health: Measuring the will and the ways. In C. R. Snyder \& D. R. Forsyth (Eds), Handbook of social and clinical psychology: The healt perspective (pp. 285-305). Elmsford, NY: Pergamon.

Snyder, C. R. (2000). Handbook of hope: Theory, measures, and applications. A Harcout Science and Technology Company: Academic Press.

Umphrey, L. R., \& Sherblom, J. C. (2014). The relationship of hope to self-compassion, relational social skill, communication apprehension, and life satisfaction. International Journal of Wellbeing, 4(2), 1-18. doi:10.5502/ijw.v4i2.1. 